\title{
Improvement of engineering soil properties using non - traditional additives
}

\author{
Mohanned Waheed ${ }^{1, *}$ and Noor Asmael ${ }^{2}$ \\ ${ }^{1}$ Building and Construction Eng. Department, University of Technology, Baghdad, Iraq \\ ${ }^{2}$ Highways and Transportation Department, Mustansiriyah University, Baghdad, Iraq
}

\begin{abstract}
Laboratory experiments are conducted to evaluate the effect of some non-traditional additives on the engineering properties of clayey soil, which show problematic phenomenon when used as a construction material. The conducted tests covered the influence of these additives on various parameters like consistency limits, compaction characteristics and CBR value. Two nontraditional stabilizers are selected in this study, polymers and phosphoric acid at three different percent which are $(1 \%, 3 \%$ and $5 \%)$ of the dry soil weight. It is concluded that addition of the polymer to the clayey soil results in a slight increase in plastic limit while the liquid limit is not affected accompanied by a marginal decrease in the dry unit weight while the optimum moisture content remains unaffected. The addition of phosphoric acid to the clayey soil has no effect on its Atterberg limits. In general, it is observed that polymer is found to be ineffective as a stabilizer to improve clayey soils, especially in small amounts of about (3\%). The phosphoric acid treated soil gained better improvement for all amounts of additive used. For $(3 \%)$ acid treated soil the CBR is about (360\%) compared to that of untreated soil, for that, it can be concluded that the improvement using phosphoric acid in the clay soils is a promising option and can be applied to solve the geotechnical stabilization problems.
\end{abstract}

\section{Introduction}

Improvement of soil properties or soil stabilization is a technique introduced for the purpose of improving poor soil properties to make it acceptable for construction in the engineering projects. The effect of additives on the engineering properties of soil has been studied by many researchers. The wide use of traditional additives such as cement, lime, fly ash, and asphalt emulsion etc. for improvement of soil led to an attempt to select other non-traditional additives, especially, a few studies have been conducted in the field of soil improvement using non-traditional additives. The variety of non-traditional stabilization additives dictated some attempts to classify these different additives according to their active composition.

A synthesis of potential stabilizers that is identified by the US Army Corps of Engineers and contract researchers for the period between (1946 -1977) was presented by Oldham et al. [1]. The results of their investigation identified cement, lime, resins, asphalt, silicates, salts, and other products as potential stabilizers demonstrating varying degrees of engineering success. The report classifies the product performance according to type of soil and demonstrated that the action was different in varying soil types.
Ajayi-Majebi et al. [2] performed an experimental work to study the effect of a mixture of an epoxy resin (bisphenol A/epi-chlorohydrin) and a polyamide hardener for stabilization of clayey silt soils. The mixing ratio of epoxy resin to polyamide hardener is (1:1 ratio). The liquid limit of the soil ranging from ( 37 to 45 ) so that the plasticity index is between (13 to 18$)$. It was observed that mixing of (4\%) stabilizer produced large increment in unsoaked CBR values.

Laboratory tests were carried out by Santoni et al. [3] for stabilization a silty-sand soil using some stabilizers. The stabilizers include enzymes, acids, polymers, tree resins, lignin-sulfonates, and petroleum emulsions. The results obtained showed excellent potential of polymers for the improvement, while enzyme and acid are failing to produce significant action for stabilization.

Zandieh and Yasrobi [4] studied stabilization of sandy soil using two different polymers. The results achieved using these polymers showed that there was improved in the compressive strength from $(0.03 \mathrm{MPa})$ for control sample to (5.2 $\mathrm{MPa}$ ) for improved sample. The intended task of this paper is studying the effect of two non-traditional additives on the engineering properties of clayey soil, especially, those soils that show a trend to be more problematic during geotechnical construction. The additives selected in this study, include polymers, and phosphoric acid. The investigation covered the influence of these additives on various soil 
properties as consistency limits and compaction characteristics.

As the California Bearing Ratio test (CBR) is widely used by the engineers to determine the suitability of a soil as a subgrade or subbase for highway and runway design and construction, therefore, it was considered in this study to evaluate the strength improvement of the soil.

\section{Materials and experimental program}

\subsection{The soil}

The soil used is extracted from Baghdad city in Iraq, standard tests were performed to determine the physical properties of the soil, and the results are presented in Table (1), while the grain size distribution is shown in Figure (1), The soil is brown silty clay and it is classified as, low plasticity clay (CL) according to the unified soil classification system.

Table 1. The properties of the soil used.

\begin{tabular}{|c|c|c|}
\hline Property & $\begin{array}{c}\text { Index } \\
\text { Value }\end{array}$ & Specification \\
\hline Liquid limit (L.L) & 48 & $\begin{array}{c}\text { ASTM-D4318-2010 } \\
{[5]}\end{array}$ \\
\hline Plastic limit (P.L) & 21 & $\begin{array}{c}\text { ASTM-D4318- } \\
2010[5]\end{array}$ \\
\hline Plasticity index (P.I) & 27 & $\begin{array}{c}\text { ASTM-D4318- } \\
2010[5]\end{array}$ \\
\hline $\begin{array}{c}\text { Specific gravity (Gs) } \\
\text { Sand (4.75mm to } \\
0.075 \mathrm{~mm})\end{array}$ & 2.69 & $\begin{array}{c}\text { ASTM-D854- } \\
2010[6]\end{array}$ \\
\hline $\begin{array}{c}\text { Silt (0.075 mm to } \\
0.005 \mathrm{~mm})\end{array}$ & $45 \%$ & $\begin{array}{c}\text { ASTM-D422- } \\
2010[7]\end{array}$ \\
\hline $\begin{array}{c}\text { Clay (less than 0.005 } \\
\text { mm) }\end{array}$ & $51 \%$ & $\begin{array}{c}\text { ASTM-D422- } \\
2010[7]\end{array}$ \\
\hline Soil Classification & CL & USCS \\
\hline
\end{tabular}

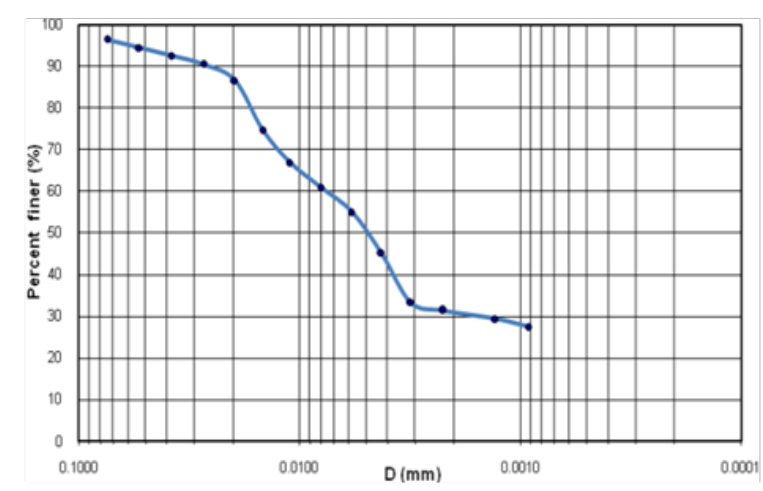

Fig. 1. Soil grain size distribution.

\subsection{Polymers}

The polymer used in this investigation is polyvinyl alcohol (PVA), which is commercially available in a granular powder state and it was odorless and tasteless, translucent white or cream colored. It is produced commercially from polyvinyl acetate, usually by a continuous process. The chemical formula is $\left(\mathrm{CH}_{2} \mathrm{CH}(\mathrm{OH})\right)$. It has solubility in water and slightly soluble in ethanol, but insoluble in other organic solvents. Typically (5\%) solution of PVA exhibits a $\mathrm{pH}$ value of about (5 to 6.5) and has a melting point equal to about $\left(180^{\circ} \mathrm{C}\right)$, while a molecular weight of between 26,300 and 30,000 , so that the degree of hydrolysis ranged from ( $86.5-89 \%)$.

\subsection{Phosphoric acid}

Phosphoric acid has varied uses (HSDB, 1995) [8]. For the industry, it is a chemical intermediator reagent in the production of numerous phosphate fertilizers, soaps, waxes, polishes, agricultural feeds, and detergents. Phosphoric acid is added to foods as a preservative, acidifying agent, flavor enhancer, and clarifying agent. It is also used in processes such as the coagulation of rubber latex, electro-polishing and as a catalyst in the production of propylene and butane polymers, ethylbenzene, and cumene .The summary of the chemical properties of Phosphoric acid according to (HSDB, 1995; and HSDB 1999[9]) is shown in Table (2).

Table 2. Chemical properties of Phosphoric acid.

\begin{tabular}{|c|c|}
\hline Property & Specification \\
\hline Description & $\begin{array}{c}\text { Clear syrupy liquid or } \\
\text { unstable crystals; odorless }\end{array}$ \\
\hline Molecular formula & $\mathrm{H}_{3} \mathrm{PO}_{4}$ \\
\hline Molecular weight & 98 \\
\hline Boiling point & $213^{\circ} \mathrm{C}$ \\
\hline Melting point & $42.35^{\circ} \mathrm{C}$ \\
\hline Vapor pressure & 0.03 torr @ $20^{\circ} \mathrm{C}$ \\
\hline Solubility & $\begin{array}{c}\text { Very soluble in hot water; } \\
548 \mathrm{~g} / 100 \text { ml cold water; } \\
\text { soluble in alcohol }\end{array}$ \\
\hline Conversion factor & $4.0 \mu \mathrm{gg} / \mathrm{m}^{3}$ per ppb at $25^{\circ} \mathrm{C}$ \\
\hline
\end{tabular}

\subsection{Laboratory tests}

The laboratory tests carried out included the determination of the Atterberg limits (liquid limit, plastic limit, and plasticity index), compaction test and CBR test. The details of these tests are illustrated in the following sections.

\subsubsection{Atterberg test}

Atterberg limits tests were carried out based on ASTMD4318-2010. These tests were conducted to investigate the effect of the additives in varied percentages on the consistency limits of the soil.

\subsubsection{Compaction test}

Compaction tests are conducted to determine the effect of stabilizers on maximum dry density (MDD) and 
optimum moisture content (OMC). Compaction test was performed according to ASTM (D1557-2012) [10], it is performed in a mold with an internal diameter of 152.4 $\mathrm{mm}$ and a height of $116 \mathrm{~mm}$. The specimens are compacted in (5) layers and number of blows equal to (56) for each layer according to modified proctor test.

The first series of compaction tests are conducted in order to find the compaction properties of the untreated soil. Secondly, tests are carried out to determine the effect of additives with varying amounts on the compaction properties. The additive is dissolved in water and then thoroughly mixed with soil. A curing period of (24) hour is allowed for the soil-additive mixture prior to compaction.

\subsubsection{CBR test}

The CBR test was considered in this research in order to study the effect of the additives on strength improvement of the soil. CBR test was conducted according to BS (1377-1990)[11]. The samples prepared for CBR tests are compacted to a maximum dry density at the optimum moisture content determined according to modified proctor compaction tests and tested directly after sample preparation .

The preparations of the specimens were achieved according to the procedures in ASTM (D1557-2012). The CBR test is performed in a standard mold of CBR with a $(4.5 \mathrm{~kg})$ rammer dropped from a height of (457 $\mathrm{mm}$ ). The soil was compacted in (5) layers with (56) hammer blows applied per lift. The test is conducted under a seating load of $(4.5 \mathrm{~kg})$ and a penetration rate equal $(1.27 \mathrm{~mm} / \mathrm{sec})$.

The $\mathrm{CBR}$ value is calculated as:

$$
\mathrm{CBR}=\mathrm{P} / \mathrm{Ps} * 100(\%)
$$

where: P : plunger-load in $\mathrm{kN}$ for tested soil.

Ps : plunger-load in $\mathrm{kN}$ for a standard soil (which is equal to $13.2 \mathrm{kN}$ for $2.5 \mathrm{~mm}$ and $20 \mathrm{kN}$ for $5 \mathrm{~mm}$ penetration), where the highest of the two values is then considered as CBR value.

\section{Results and discussions}

The effectiveness of the stabilizer for soil strength improvement was studied by mixing varying amounts of additive with the soil samples, and performing the tests in the laboratory. Three different amounts of additive for each of phosphoric acid and polymer are selected for this study, ( i.e., 1, 3 and 5\%) of the dry soil weight. The effect of each additive on soil properties is described as follows.

\subsection{Effect of polymer}

The effect of polymer addition on Atterberg limits is shown in Figure (2), it can be seen that there is a small decrease in plasticity index due to a slight increase in plastic limit as the polymer content increased, while the liquid limit showed a negligible increase.

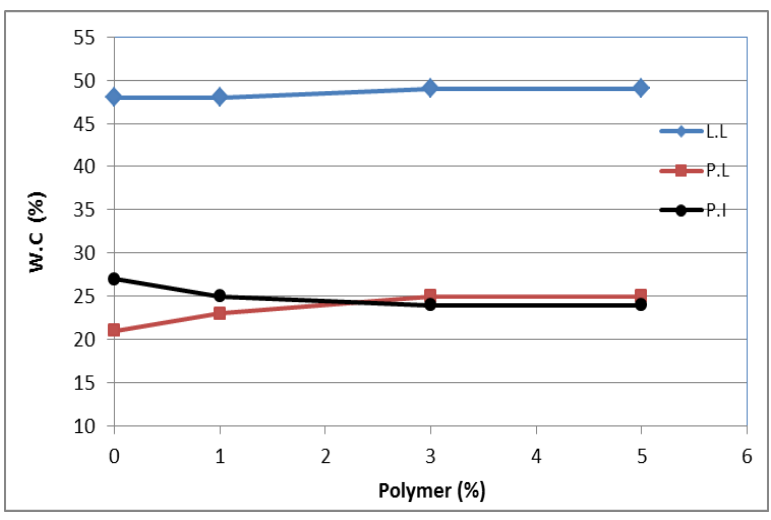

Fig. 2. The effect of polymer on Atterberg limits.

The compaction curves for untreated and treated soil with different percentages of polymer are shown in Figure (3). It is noticed that increasing the polymer contents marginally decreases the dry density except for the addition of $(5 \%)$, where a marked decrease in the dry density value was observed, while the optimum moisture content is not affected in all cases. The decrease in the dry density may be attributed to the clay polymer interaction, as it is believed that the polymer flocculates the particles and spreads them apart resulting in a volume increase of the sample and so reducing its dry weight.

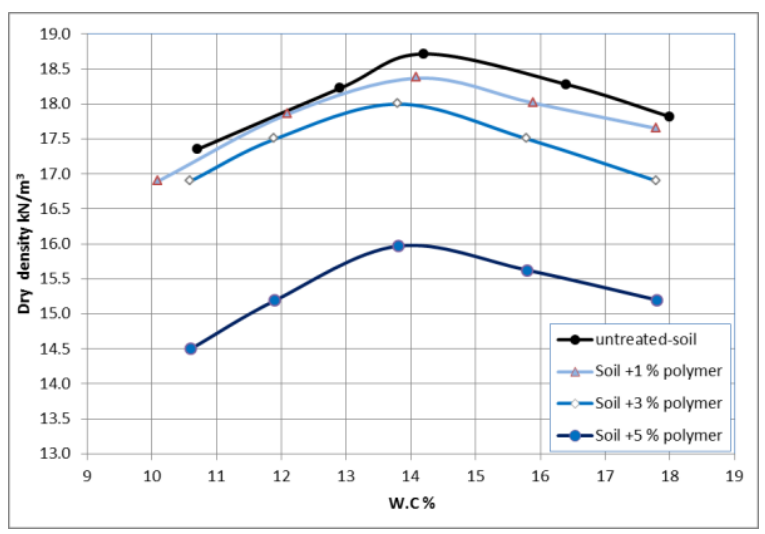

Fig. 3. The relation between dry density and water content for different percentages of polymer used.

The load-penetration curves of CBR test for untreated and treated soil with polymer are shown in Figure (4), and the CBR values of untreated and treated specimens using the two additives are given in Table (3), it can be observed, in general, that the addition of polymer led to a significant increase in the CBR values only in case of addition (5\%). 


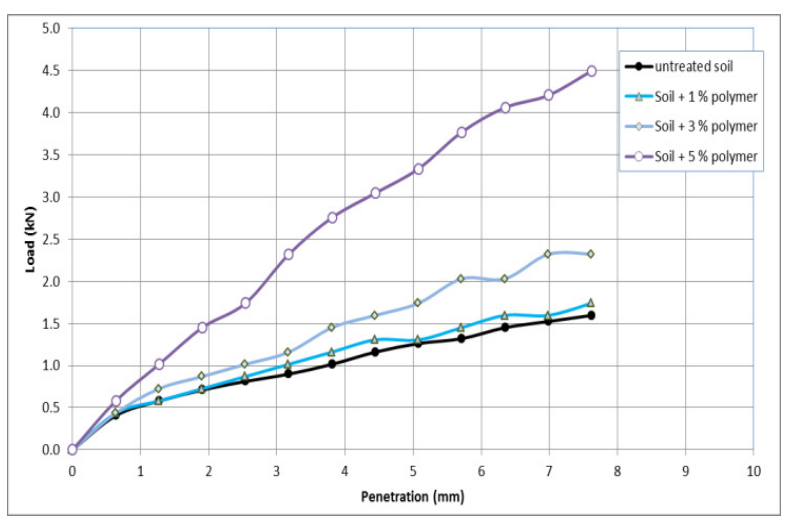

Fig. 4. The load-penetration curves of CBR test for untreated and treated soil with polymer.

\subsection{Effect of phosphoric acid}

The effect of adding phosphoric acid on Atterberg limits is shown in Figure (5), it is observed that there is no noticeable effect on the liquid limit, however, there is a slight decrease in the plasticity index due to a slight increase in plastic limit. In general, it is found out that the effect of acid is almost absent on Atterberg limits.

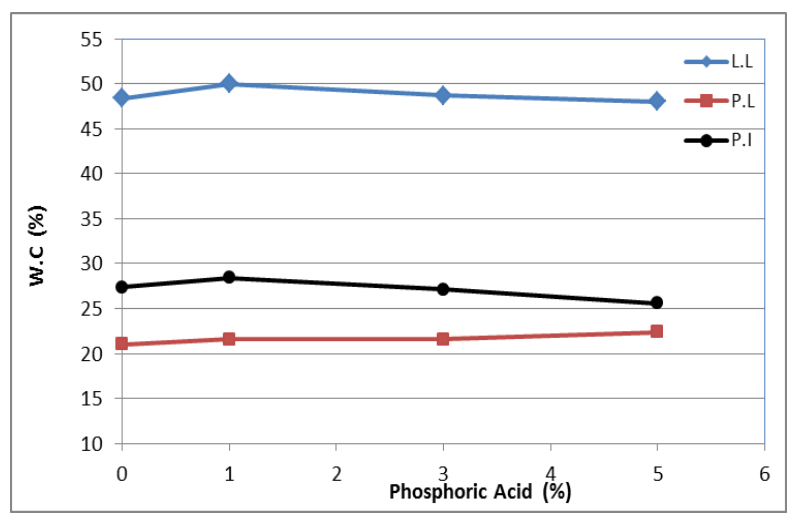

Fig. 5. The effect of phosphoric acid on Atterberg limits.

The effect of adding phosphoric acid on the compaction characteristics is shown in Figure (6). It is observed that increasing the phosphoric acid content decreases significantly the dry density and increases slightly the optimum moisture content, however, OMC arise from (14.3\%) for untreated to about $(15.4 \%)$ of the soil treated with ( $5 \%$ ) acid, while the density declines from $\left(18.7 \mathrm{kN} / \mathrm{m}^{3}\right)$ to $\left(17.9 \mathrm{kN} / \mathrm{m}^{3}\right)$ respectively.

The effect of Phosphoric acid on the load-penetration curves of CBR test for untreated and treated soil are shown in Figure (7), it can be seen, in general, that the addition of acid causes a significant increase in the CBR values for the three different percentages of addition, moreover, the next paragraph shows the percentage of strength improvement in CBR for the three amounts for the two different additives used.

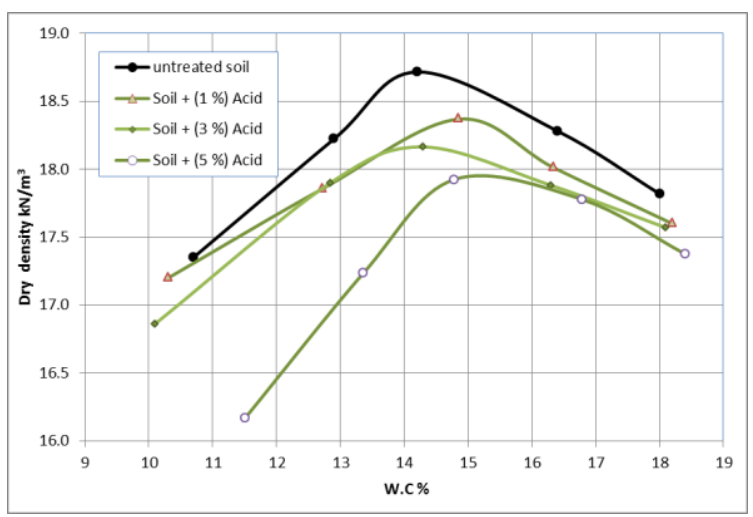

Fig. 6. The relation between dry density and water content for different percentages of Phosphoric acid used.

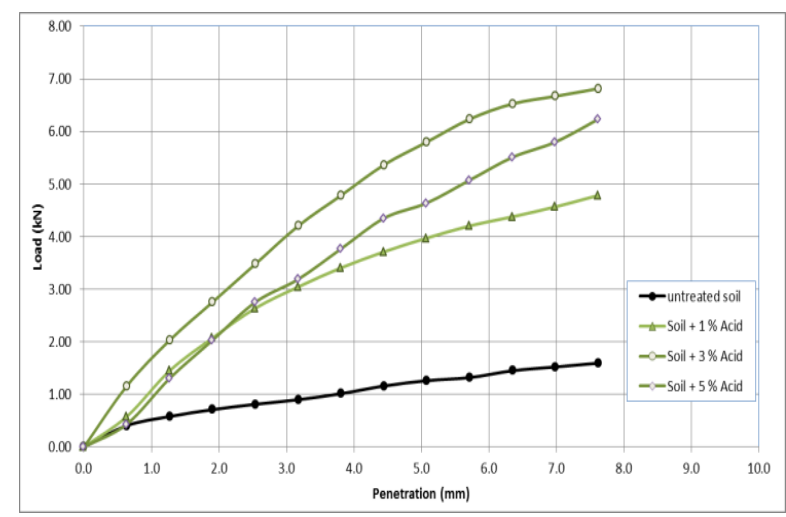

Fig. 7. The load-penetration curves of CBR test for untreated and treated soil with Phosphoric Acid.

\subsection{Effect of stabilizer type on strength improvement}

For comparison purposes, the strength improvement in the CBR in percent to that of the soil treated with polymer are drawn together with those treated with phosphoric acid in Figure (8), at the three different percent. It can be observed from this figure, that the addition of (1-3\%) polymer to the clayey soils causes an increase of $(8-40 \%)$ in the CBR value, while it increases to about ( $160 \%)$ for addition of $(5 \%)$ polymer.

In general, it can be said the stabilization with polymer in clayey soil gives poor results with respect to strength improvement, especially in less amount.

On the other hand the CBR has improved between (200 to $360 \%$ ) due to the addition of phosphoric acid and the maximum value corresponds to a $(3 \%)$ of phosphoric acid addition. It can be concluded that the improvement using phosphoric acid in the clay soils is a promising option and excellent results can be expected.

Similar results were reported by (Lyons and McEwan [12] and Medina and Guida [13], however, it was pointed out that using phosphoric acid for treatment of kaolinite clays has been brought several benefits in soil properties such as improved strength and workability . 


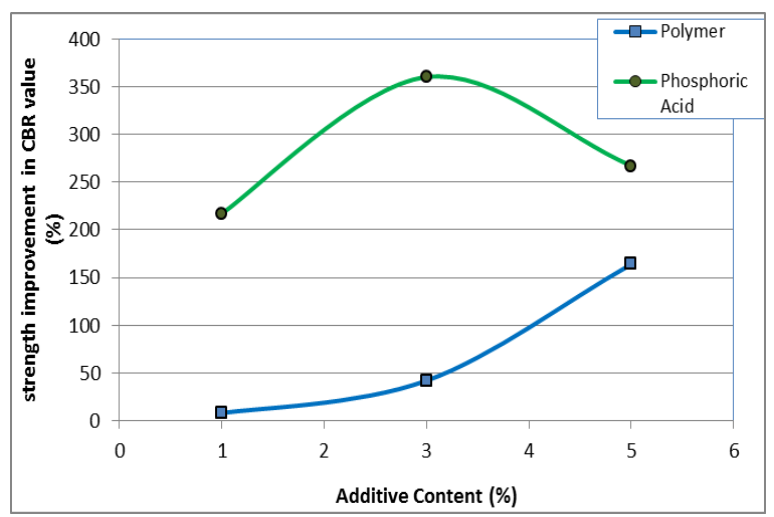

Fig. 8. strength improvement in the $\mathrm{CBR}$ value of the soil treated soil with polymer and Phosphoric Acid.

Table 3. Values of CBR of Untreated and Treated Specimens.

\begin{tabular}{|c|c|c|c|}
\hline Case & $\begin{array}{c}\text { CBR } \\
\text { (At 25 mm } \\
\text { penetration) }\end{array}$ & $\begin{array}{c}\text { CBR } \\
\text { (At 50 mm } \\
\text { penetration) }\end{array}$ & CBR \\
\hline Untreated Soil & 6.15 & 6.31 & 6.31 \\
\hline $\begin{array}{c}\text { Soil + 1\% } \\
\text { polymer }\end{array}$ & 6.59 & 6.53 & 6.59 \\
\hline $\begin{array}{c}\text { Soil + 3\% } \\
\text { polymer }\end{array}$ & 7.69 & 8.7 & 8.7 \\
\hline $\begin{array}{c}\text { Soil }+5 \% \\
\text { polymer }\end{array}$ & 13.18 & 16.68 & 16.68 \\
\hline $\begin{array}{c}\text { Soil }+1 \% \\
\text { Acid }\end{array}$ & 19.99 & 19.87 & 19.99 \\
\hline $\begin{array}{c}\text { Soil }+3 \% \\
\text { Acid }\end{array}$ & 26.36 & 29 & 29 \\
\hline $\begin{array}{c}\text { Soil }+5 \% \\
\text { Acid }\end{array}$ & 20.87 & 23.2 & 23.2 \\
\hline
\end{tabular}

\section{Conclusions}

Based on the results of the tests conducted throughout this task, it can be concluded that:

1. Adding polymer to clayey soil causes a slight increase in plastic limit while the liquid limit is not influence, and marginally decreases the dry density while the optimum moisture content was not affected in all cases.

2. In general, it can be said that the effect of phosphoric acid is almost négligeable on Atterberg limits, however, there was a slight decrease in the plasticity index due to a slight increase in plastic limit .

3. Increasing the phosphoric acid content decreases significantly the dry soil density and slightly increases the optimum moisture content.

4. It is found out that the polymers are inefficient in soil stabilization, especially when added at low percent.

5. The phosphoric acid-treated soil gained more strength improvement for all amounts of additive used, which can be up to $360 \%$ relative to untreated soil for the addition of $3 \%$ acid.
6. The stabilization using phosphoric acid in the clay soils is a promising option and excellent results can be expected to solve the geotechnical stabilization problems.

\section{References}

1. J.C. Oldham, R.C. Eaves, D.W. White. Miscellaneous Paper S-77-15, U.S. Army Engineer Waterways Experiment Station, Vicksburg, MS, September (1977).

2. A. Ajayi-Majebi, W.A. Grissom, L.S. Smith, E.E. Jones. National Research Council, Washington, D.C. (1991).

3. R.L. Santoni, J.S. Tingle, S.L Webster. TRB paper 02-3756, TRB January (2002).

4. A. Zandieh, S. S. Yasrobi, Geotech. Geol. Eng. 28:139-145 (2010).

5. ASTM-D4318, Standard Test Method for Liquid Limit, Plastic Limit, and Plasticity Index of Soil, (2010).

6. ASTM-D854, Standard Test Method for Specific Gravity, (2010).

7. ASTM-D422, Standard Test Method for Particle Size Analysis of Soils, (2010).

8. Hazardous Substances Data Bank. National Library of Medicine, Bethesda, Maryland. Denver, CO: Micromedex, Inc. (1995).

9. HSDB. Hazardous Substances Data Bank. Available online at http://sis.nlm.nih.gov, (1999).

10. ASTM-D1557, Standard Test Methods for Laboratory Compaction Characteristics of Soil Using Modified Effort (2012).

11. B.S. Methods of test for soils for civil engineering purposes, 1377-4, (1990).

12. J.W Lyons, G.J. McEwan, Highway research board bulletin, Washington DC, 318, 4-14, (1962).

13. J. Medina, H.N. Guida, Journal of Geotechnical \& Geological Engineering 13:199-216 (1995). 